\title{
POSTGRADUATESTUDIES ON RELIGION IN SOCIAL SCIENCES AT UERJ: THE CONTEXT OF RIO DE JANEIRO AND RECENT PRODUCTION
}

\author{
Cecília Mariz
}

Clara Mafra ${ }^{1}$

\begin{abstract}
In this article we describe the research group on religion of the Postgraduate social sciences programme at UERJ: its setting up, profile of the members, recent production and the dissertations and theses supervised by its members. In order to contextualize this group, first we did a short retrospective historical overview of the study of religion in Rio de Janeiro discussing the role that non-governmental organisations had in encouraging research on religion, highlighting the Institute of the Study of Religion (ISER), and the role of post-graduate programmes.

Keywords: Social Sciences; Religion; NGO; Postgraduation programme; ISER.

Being the cradle of Umbanda and the Universal Church of the Kingdom of God, Rio de Janeiro stands out in Brazil not only for generating religions, but also for the production of data and analyses of this phenomenon. ${ }^{2}$ Amongst the various postgraduate social sciences programmes in this state, ${ }^{3}$ the one from Rio de Janeiro State University, UERJ, which is the subject matter of this article, is one of the more recent ones, although it currently brings together the most professorsresearching the subject of religion. Before we turn to our analysisof the social sciencesreligious researchgroup at UERJ,

\footnotetext{
${ }^{1}$ Both are professors at the State University of Rio de Janeiro- Brazil

${ }^{2}$ In her thesis on the study of religion in Brazil, Sonia Reyes Herrera (2004:284/5) observes the concentration of research groups in the anthropology of religion in Rio de Janeiro.

${ }^{3}$ Weare referring to the National Museum (Anthropology), IUPERJ (Sociology and Political Science), UFRJ(Sociology/Anthropologyand Political Science), UFF (Anthropology, Politics and Sociology), UFRRJ (CPDA),PUC (Social Sciences).
}

Debates do NER, Porto Alegre, ANo 8, N. 11, P. 21-47, JAN./Jun. 2007 
its recent production and the dissertations and theses supervised, we shall try to give a historical retrospective ${ }^{4}$ of the study of religion in Rio de Janeiro. First, we shall discuss the role that non-governmental organisations and their social projects have had in encouraging research on religion, highlighting the Institute of the Study of Religion (ISER), as almost all the members of this research group at one time or another have been involved with this organisation. With this analysis we hope to offer assistance in better understanding theissuesresearchedby thegroup, and thepathsand partnerships of its members.

\section{SOCIAL SCIENCES AND RELIGION IN RIO DE JANEIRO: A HISTORICAL RETROSPECTIVE}

To the uninformedvisitor, the high concentration, even today, of groups studying religion in the social sciences at Rio de Janeiro universities may seem odd. Very easily, a foreign guest, for example studying Afro-Brazilian religiousness, might find him or herself surrounded by "specialists on the topic", all from universities and research centres in the region, having to respond to commentaries and criticisms in the most varied of intellectual traditions (from Weberian or Durkhei mian structural-functionalism, symbolic-interactionism, post-structuralism, a more Focaultian contribution or performatic viewpoint of the culture). What mighthave causedthis strange attractionto a fieldwhich, despite all the criticismof revision, continuesoutside the confinesof most of western thought,asked one of these intriguedvisitors?

It seems to us that this special interest arose exactly during the turn of the 1970's to the 1980's, when the experiments in social intervention organised by the churches and the left-wing parties and their emphasis of a product aimed at "popular education" together with the "bases" coincided with the dynamics of setting up postgraduate courses, strongly directed towards the

\footnotetext{
${ }^{4}$ We thank very much Waldo César, Otávio Velho and Patrícia Birman for theirinterviews that helped us to tell this story. We would also like to thank Paulo Victor Leite Lopes, Janine Targino, Patrícia Silveira and Rosiane Silva for the transcription of these interviews.
} 
creation of ethnographic approaches, placing value on the study of the "familiar". Without this having been planned, the studies on religion in contemporary Rio de Janeirogave rise to a revitalisation through this meeting of perspectives, without which, intellectual production would have been doubly embarrassed: whether by the concern of being placed "in an ivory tower", as many activists think of the university research centres, or in the aversionto an excessively partialproductionof knowledge, albeit"opportunist and interventionist" - an accusation which goes in the other direction.

In the following pages, we shall bring back to the surface some of the unsettled timeswhich accompaniedthe setting up of the firstnuclei of research into religion in Rio de Janeiro, outside (but not far from) the churches and universities,such as the Institute of the Study of Religion (ISER), the Centre of Religious Statistics and Social Investigations (CERIS) and the Brazilian Institute of Social Development (IBRADES) ${ }^{5}$. Then we shall return to the setting up of the first postgraduate study centres back in the 1960's, and their impact on the new conditions of production of teachingand of research. Lastly, we shall enquire into the emergence of another academic task as a result of this regional process, bearing in mind the success of the universities as centres of production teaching and research in the social sciences in Brazil.

\section{THE EXPERIENCE OF THE ACTIVIST NGOS}

According to Leilah Landim (1998), in Brazil, the environment of the setting up of the first non-governmental organisations was notable for its large degree of informality, necessary invisibility and the strong emphasis on personal relationships. With the coming of the dictatorship, many of the people who worked in the field of education prior to 1964, whether religious or otherwise, ended up having to restrict their activities and to dedicate themselves to a semi-clandestine set of skills. These people were a group who

\footnotetext{
${ }^{5}$ The role of the NGOs in stimulating research, especially ISER in the case of religion, has already been highlighted by various authors, amongst others see Oro (1993), Camurça, (2001), Mariz, (1993).
} 
had gone through the work on the "base" in political parties and organisations, or who had circulated in the new pastoral activities in the Theology of Liberation or with the World Council of Churches and other ecumenical bodies. Between one job and the next, they ended up "helping out" here or "working on the base" there, "promoting the work of popular education over the years", and thus gaining skill in assessment of those people so-called "committed to" or "working for" the popular classes. Unlike their academic peers, this kind of skill was built in the practice, in action and through the living together with "the bases".

To put it in a better way, "helping out" in this context means to act as a mediator between the numerous and culturally distant "bases" and the rare and hard to find external agents. In many cases, the leading edge came from a rich and rebuilt Europe and arrived with the enormous task of reform. In this case, mediating as a representative of the tropics could imply working through moderation, with modelling and adjustment of a certain charitable urge but with an authoritarian self-confidence.

So, an example: existed...[and still exists today, but to a lesser degree]...organisations that worked with technology, appropriate technology... This was the fashion in the seventies ... Technologies suited to each situation. There was a place in the Bolivian uplands at 4,000 metres in altitude where it would take half an hour to make coffee. The fire was rarefied, the air was rarefied, the oxygen burnt very quickly and the water took a long time to heat up. I once asked for a coffee there and I waited for an hour, the women there, fanning the fire... A technology group went there and said "Madam, let us solve your problem!" They brought stoves with a hole just the right size to hold the pan so as not to lose the heat. That was fantastic, yes?! Under one kind of logic, yes... But the husbands rejected the project completely. Why? 'What will the women do, after using the stove, what are they going to do? They have to work!' This was the thought there. (Waldo César, November 2006).

Some projects arrived for the first time in far-flung corners of Brazil and LatinAmerica, reaching populations completely immersed in localloyalty networks. In general, the projects were designed to replace relationships of

Debatesdo NER, Porto Alegre, ano 8, N. 11, P. 21-47, JAn./Jun. 2007 
dominationcrystallised over time. Togetherwith the possible and foreseeable glimpse of the opening of the world of the "bases", a cultural shock very often occurred. The upsets and emergence of new conflicts demanded continuity in the accompaniment. And so, the projects were renewed, not once, but several times, bringing together the same "base" and the same "helpers" over the years. With the passing of the years, with more and more projects implemented and under development, the need to bring together the mediatorconsultantswas perceived.

There was one project that went like this: I want you to bring together all the organisations working in this field. So people got together and met who had not even known each other beforehand. The debate took unexpected turns because people were discovering: "Goodness, you're doing this too?!". Well, it stirred things up like nothing else, something fantastic! (Waldo César, interview November 2006).

ISER $^{6}$ was being set up, as was common at the time, as a "group of friends", albeit, a large group, consisting of at least three different circles. One rather large circle of ecumenical Christians, many of them originally protestants, who later moved over to the University. Here we find Rubem Alves(first president of ISER),WaldoCésar (witha stintat the World Council of Churches), Richard Shaull (Methodist pastor), Rubem César Fernandes (who returned from exile in 1974). Then there was the Catholic circle of "church intellectuals", such as Alberto Antoniazzi, Francisco Cartaxo Rolim and Pedro Ribeirode Oliveira. Finally, another circlewas the strictlyacademic people. The method was improvisation, sustained by informality and the objective was rather vague.

${ }^{6}$ The ISER (Institute of the Studies of Religion) arose out of ISET (Institute of Higher Studies of Theology), which basically consisted of ecumenical protestants connected with the World Council of Churches through out the 1950's and 60's. ISER was set up in Campinas in 1970 and was transferred to Rio de Janeiro in 1973 (Fernandes in interview with Novaes, 1997, and Reyes Herrera, 2004). 
ISER has brought together researchers into religion since the 1970's, with Rubem Alves as president. The headquarters was in Rubem's house, who was professor of philosophy at Unicamp. In the seventies, ISER met twice a year. It was a group of researchers, from various places in the country, who met periodically, generally on a weekend where a seminar was organised, each time around a theme, and people brought a paper and got together. It was a network of researchers and a network of friends. The two things were combined. (Rubem César Femandes in interview with Regina Novaes, 1997, p. 8).

In the 1980s,in Rio de Janeiro,ISER broadensits networkof researchers integrating post-graduate professors and students. Unlike other NGOs, besides interventionist projects ISER developed strictly academic research projects. During this period ISER became one of the most important centres of reference in Brazilian social sciences research into religion. At that time, it is worth calling particular attention to the research group on Catholicism, co-ordinated by Pierre Sanchis. This group gathered a wide network of professorsaffiliatedwith universitiesfrom all overBrazil and carried out various projects supportedby $\mathrm{CNPqNationalResearch} \mathrm{Council)This} \mathrm{groupproduced}$ several important articles and books which had an impact on the academic field (see for instance, Sanchis, 1992a; 1992b; 1992c). Ralph Della Cava, Carlos Rodrigues Brandão, Paula Montero, Regina Novaes, Raymundo Heraldo Maués, Francisco Cartaxo Rolim, Pedro Ribeiro de Oliveira, Ana Maria Doimo, Carmem Cinira Macedo, José Ivo Follmann, among other people, participated of this group. As a result of this academic profile of ISER, there were also the research projects co-ordinated by Rubem César Fernandes which produced the "Censo Institucional Evangélico"(Evangelical Institutional Census, 1992)" and the book "Novo Nascimento - os evangélicos em casa, na rua e na cidade" (New Birth - the evangelists at home, in the street and in the city, 1994). Both had a great impact on the reflection on religion in the country.

ISER grew considerably such that in 1995 it was subdivided, and various groups within ISER set up other NGOs. It was at this time that the "Base Organisations and Religious Bodies Consultancy Team", which had been set 
up within ISER in 1982, became an autonomous non-governmental organisation:ISERAssessoria.

Although each had there own style, ISER and ISERAssessoria shared some similarities along with other NGOs, in that they administered funds from abroad in supporting consultancy and research projects with social and religious movements, and in identifying themselves with certain goals of social intervention. Unlike ISER, CERIS, whose activities were brought to an end in 2007, stood out as being responsible for producing the Catholic Yearbook and, therefore, for its connections with the Brazilian Council of Bishops (CNBB); whilst IBRADES had connections with the Jesuits. Years later, KOINONIA was set up. For the purposes of this article we would like to point out three characteristics which these organizations had in common:

1. They set up spaces which are less about spreading certain knowledge or social technology than the forums set up by the state and by the Church, and more about experimentingwith the interlocutionbetween Brazilian and foreign mediators, "consultant-researchers" and there "bases". This space is crossed with a promise of setting up a broad civic culture, although with the strong motivation in "mobilizing" to "qualify" the "bases", and/or working with the great need to "convince the funder", aspects which tend to result in a certain incapacity to absorb the differences. Years later,in the article "Besta Fera" ("Beast of Revelation"), Otávio Velho (1987 and 1995) suggests some limitsto this interlocution.In this article, Otávioremembers that a generation of researchers who went to the field in search of "popular resistance", seemed incapable of recognizing it in its most subtle and lasting dimension, as for example in the metaphor of the "Beast of Revelation" and in the countless references of everyday peasant language to a widespread biblical culture.

2. These organizations were born in informality and based themselves on loyalty networks and personal or religious relationships, however they refuse to be "yet another part of the system". Their future horizon is the creation of a "public persona", ideally establishing themselves as a centre of reference, of elaboration and of production of cultural policy to a significant group of interlocutors. It was not a question of transforming the organisation into a centre,concentrating resourœs and knowledge, enabling the rethinking 
of a nation, as would be expected of a political party type structure, but neither did they want to compromise and just follow the "rules of thumb" in search of resolving needs which were always of circumstance and partial. This expectation was true on various levels.

3. As these organizations did not belong to the state and were not part of the university system, for certaintimes they had the autonomyand freedom necessaryto carry out projects of co-operationbetween respectedinstitutions which otherwise would have been difficult to do because of bureaucratic obstructions. Due to its academic research contributions, ISER earned recognition and became a member of the National Social Sciences Postgraduate Association (ANPOCS).

It is also worth stressing that during this period the journal Religião $e$ Sociedade (Religion and Society), was the principle means of publicising the nucleus of intellectuals' research and ideas at ISER. Helping in the integration of these intellectuals, this journal became a benchmarkin the field of research into religion in Brazil and abroad.

Religião e Sociedade is now one of the oldest academic journals in the country with 30 years of publication. Based at ISER, it is now edited by a committee whose members are from different universities: three from UERJ, two from UFRJ, one from UFGRS and one from UFMG. It has been recognised as National Level A by Qualis and has been financed by CNPq throughout its life, and it has certainly gathered the largest concentration of articles by academic authors in the areas of sociology and anthropology of religion in Brazil.

\section{THE POSTGRADUATE EXPERIENCE}

The 1960's was also the period when the first postgraduate programmes were set up in Brazil. In Rio de Janeiro, not without resistance, one of the first post-graduate anthropology programmes, the Postgraduate Programme in Social Anthropology, was formed at the National Museum in 1968. In order to make a break with the chains of a certain anti-intellectual prejudice then in effect, including from within the university, Professor Roberto 
Cardoso de Oliveira looked to establish an external partnership with the Latin-American Social Sciences Research Centre (c.f. Velho 2006, p. 11). The times were different, the idea of a future favourable to quality teaching andresearch didnot necessarilyresultin recognitionfrom academia. During this same period, postgraduate programmes in sociology were set up at IUPERJ (1969) and at UFRJ-IFCS(1968). The Rio de Janeiro StateUniversity, which had been established in the 1960's, however, was not included in this project. During this time, it was involved only in undergraduate teaching.

The research on religion at the universities in this period occurred especially in the anthropologyprogrammesand was focused almostexclusively Afro-Brazilian religions. In 1974 Yvonne Maggie defended her Master's dissertation "Guerra de Orixás" (Orixás' War), the first dissertation on religion at the National MuseumThe Social Anthropology Programme. breaks with the intellectual heritage led by Roger Bastide and his proposal of "split identity". Adopting the British structural functionalism approach, this author broke with the evolutionist intellectual heritage led by Roger Bastide. She also broke with Bastide's search for Candomblé "purity" and "authenticity" and with his proposal of Brazilian Black racial "split identity". Instead she analysed the everyday social dynamics of Candomble "terreiros" in order to understand the possession within the contemporary context of Brazil. So YvonneMaggie inaugurated a new approach to Afro-Brazilianreligiosity studies that can also be found in several authors of this period, such as Peter Fry and Patrícia Birman. Reviewing the bibliography of this period, Patrícia Birman (2007) states: "instead of trying to give an answer to what was the contribution of Candomblé to the Brazilian nation? or, how "mixed" cults integrate Blacks in Brazilian society, some authors started to study these cult for themselves: what they are, what their members do".

Another hallmark amongst the first National Museum Master's theses was "Os Escolhidos de Deus" ("God's Chosen Ones") by Regina Novaes in 1975. In this work, the author accompanies the conflicts and tensions occurring in a small town in the interior of the north-east whose tradition is Catholic, with the firstconversionsof some peasantfamiliesto Pentecostalism. In this current, a dialogue is established with the great founders of the social 
sciences - Marx, Weber and Durkheim. Here, the tradition of studies of community, an inheritance from the Chicago School, and a dialogue with the non-governmental organisations,inspired by the Theology of Liberation and the social movements, led to a more direct interlocution with the Christian traditions.

It can, however, be seen that whereas the NGOs were mobilised by the Theology of Liberation, academia and especially the programmes in anthropology were almost unaffected by this religious current in the 1970's and 1980's. In a similar fashion, there was no exchange between the studies of the Afro-Brazilian religions and the research by the NGOs. These studies carried out in academia had no dialogue with the Theology of Liberation, and vice-versa, as Patrícia Birman pointed out (interview November 2006). As a result, practically nothing was produced by the NGOs about umbanda or candomblé who were more interested in the possibility of "social consciousness" via the political or Christian route but in other fields of research on religion, exchange was very frequent between academia and NGOs.

It was common to find professors and researchers within academia in the various disciplines of the social sciences carrying out research and implementing various projects in non-governmental organisations. In the field of research on religion, however, this exchangewas very strong involving professorsand postgraduate studentsof anthropology. Sociologists connected to postgraduate programmes were involved in NGOs in other areas of work and research.

Because of the hegemony of the Marxist approach in most of the sociologyand politicalscience programmes, there was little scope for carrying out research into religion. The sociologists of religion who were active in the NGOs were either professors in the universities such as Waldo César and Luiz Alberto Gómez de Sousa or were professors at universities where there were no postgraduate programmes yet, such as Pedro Ribeiro de Oliveira (professor at UERJ until 1991) and Francisco Cartaxo Rolim (professor at UFF until his death in 1997). We also note that the doctoral work of these professors occurred outside Rio de Janeiro (Luiz Alberto Gómez de Sousa in France,Pedro Ribeirode Oliveirain Belgium,FranciscoCartaxo Rolim at USP).

Debatesdo NER, Porto Alegre, ANo 8, N. 11, P. 21-47, JAN./Jun. 2007 
Before the 1990's, it was almost impossible to study sociology of religion at a post-graduate programme in Rio de Janeiro. Those who were interested in this area had to look to anthropology. The theoretical hegemony of Marxism in postgraduate sociology programmes did not see religion as a relevant questionin contemporary societies,but rather as somethingof non-industrial societies which would making it suitable for study by anthropologists, who in general preferred to study Afro-Brazilian religion. In Brazil in this period the Theology of Liberation inspired research and activism in NGOs, but not in the universities and post-graduate programmes, although sometimes the researchers were the same. ${ }^{7}$

With the crisis in Marxism and then the fall of the Berlin Wall, this activism cooled down. Paradoxically the universities became more interested in religion and the research in the NGOs went into crisis.

\section{UERJ RELIGION AND SOCIAL MOVEMENTS RESEARCH GROUP}

As has already been underlined, academicand postgraduate researchhad been inseparable projects in Brazilsince the startof the reformof the university system at the end of the 1960's. The systematic support of research by bodies in Brazil has always been linked to the setting up of postgraduate courses. At the end of the 1960's and the beginning of the 1970's, master's degree courses were greatly encouraged.

We should remind ourselves that unlike the Federal University of Rio de Janeiro, the management at UERJ decided to invest in postgraduate and research programmes only as of 1990 . At the beginning, investment was concentrated in four postgraduate projects. The programmein social sciences

\footnotetext{
${ }^{7}$ At Louvain (Belgium), Marxist sociologists with a Roman Catholic background were very much concerned with religion. See, for instance, the work of those supervised by François Houtart. It can be noted that the sociologists concerned with religionwere either Weberian, such as Cândido Procópio and his schoolin São Paulo, or Marxist with roots in the Theology of Liberation.
} 
was one of these, as there was already a body of people with master's and doctorates who had come out of the National Museum and IUPERJ. In the lead of this group of professors were Patrícia Birman, who both in her master's and doctorate researched Afro-Brazilianreligion, and MárciaLeite and Sandra Sá Carneiro, who at the time did not have doctorates and were master's graduates from IUPERJ and PPGAS/National Museum respectively.

In March 1994 the first group studying for the master's degree in social sciences began. In this period, the only tenured professors connected with the line of religion were Patrícia Birman and Luiz Rodolfo Vilhena, who was at that time carrying out his doctoral research at the National Museum.

With the opening of teaching positions and in 1995, the tenured professorships who were researching religion increased with the entrance of Cecília Mariz (a sociology master's degree from Pernambuco Federal University and doctorate from Boston University) and Márcia Contins (master's from PPGAS/National Museum and doctorate from ECO, UFRJ).

From 1998 a doctorate coursewas planned, the postgraduateprogramme was reorganised and the abbreviation PPCIS was adopted, and new groups and lines of research were set up. The line of research into religion, which had been lost when Professor Luiz Rodolfo Vilhena died tragically in an accident in 1997, was broadened and came to be known as research into "Religion and Social Movements" incorporating Professors Márcia Leite (who would defend her doctorate at IFCS in 2000), Rosane Prado (Master's and Doctor from PPGAS/National Museum). Whereas Márcia Leite has been working on social movementsagainstviolence, RosanePrado hasbeen working on the environmentalist movements.

The first group studying for doctorates started in August 1999. Two new professors came into this group after the doctorate programme started. Clara Mafra, with a master's degree from Unicamp and doctorate from PPGAS/National Museum with a thesis on the Universal Church of the Kingdom of God (Mafra, 2002), came in via the public examination in 2000, and Sandra Sá Carneiro joined the group after defending her doctoral thesison theSantiagode Compostela pilgrimage (Carneiro, 2003) at IFCS/UFRJ.

This group of professors is registered in the CNPq directory as a group researching "Religiousness in the Urban Environment", whose leaders are 
Patrícia Birman and Cecília Mariz. Bringing together sociologists and anthropologists, the group explores, within certain common concerns and questions, not only the presence, the diversity and the many forms of religious practices and their articulationsin social life, but also various modes of social movement. The book organised by Patrícia Birman (2003) Religion and Public Space offers a panorama both of the type of production by the group up to that year and their partnerships. We do not intend to analyse this production or the partnerships here, but rather point out the themes worked on by the professors in their most recent publication s (mostly from 2005 to 2007) and by their students in their theses and dissertations. It is worth remembering that, as is stated in the summary of the $\mathrm{CNPq}$ directory itself, the priority of study of this group, but not exclusively, is religious phenomenon.

The accelerated growth of Pentecostalism as of the 1980's in Brazil has stimulated reflection of many researchersin the social sciences and the UERJ group is no exception. All the members of the group have done some type of work in this field, but this question has been analysed most by Clara Mafra, Patrícia Birman, Cecília Mariz,Márcia Contins and their graduate students.

Apartfrom her bookbased on her doctoral thesison the UniversalChurch in Portugal (Mafra, 2002), Clara Mafra has published a book on the history of the Protestantism in Brazil (Mafra, 2001) along with various articles on Pentecostalism in Rio de Janeiro (Mafra, 2007 e Mafra e Swatowiski 2007), and also in Rondônia, the Brazilian state with the highest percentage of Protestants, most Pentecostals (Mafra, 2006). Another areas of interest to Clara has been the relationships between religion and the city and also the between religion and violence, themes she has work in collaboration with Ronaldo Almeida (Cebrap/Unicamp).

In her most recent work, Patrícia Birman (2006) has focused on the activities of the Pentecostals in the public sphere and in the media. This authorhas, however, investedheavily and publisheda lot on other expressions such as Afro-Brazilian religiousness (Birman, 2007; 2005a), and also on the relationship between religion and public space, especially on such groups as the "sects" in French society (Birman, 2005b). Another area of interest of 
this professor has been the social movement against violence, as is clear in the publication of the book Mural da Dor (Mural of Pain), co-authored with Márcia Leite (Birman \& Leite, 2004).

Despite having various publications on the Pentecostals, in her most recent work Cecília Mariz has returned to the theme of Catholicism (Mariz, 2005; 2006 and also Mariz; Machado; Drogus; Stewart-Gambino, 2005 and Machado; Mariz, 2006). Nevertheless Pentecostalism is still amongst her concerns(Mariz \& Machado,2006). In co-authorship with VitóriaPeres, she also researched and published on Islam (Peres \& Mariz, 2007). Besides the partnerships with Vitória Peres of the Federal University of Juiz de Fora and Maria das Dores Machado from UFRJ, Cecília has written jointly with Marjo deTheijeof theVrijeUniversiteit of Amsterdam(Theije\& Mariz, 2008).

There are two themes which stand out in Sandra Sá Carneiro's recent work: the pilgrimage routes and religious teaching in public schools in Rio de Janeiro. Her interest in pilgrimages arose out of her doctoral thesis on the Brazilian pilgrims in Santiago de Compostela, Spain (Carneiro, 2003a and e 2003b). Her interest has now broadened out to the new pilgrimage routes recently opened in Brazil (Carneiro, 2004a) and to religious tourism (Car neiro \& Freire-Medeir os, 2005). This work has been done in partnership with Carlos Steil from UFRGS. In her study on religious teaching, Sandra exchanged with Emerson Giumbelli from UFRJ and also with ISER (Carneiro, 2006).

Alongside but also inter-related with her study comparing Pentecostal Charismatic Catholicsand popular Catholicism devotionto the Holy Ghost, Márcia Contins (2005 and Contins \& Campos 2007), has also dedicated herself to the study of the ethnic question, especially the people of African descent in Brazil. She has published on the Afro-Brazilian Pentecostals (Contins,2004b) and also about Afro-Brazilian leadership and affirmative action (Contins, 2005b e 2004a). Besides the collaboration with José Reginaldo Gonçalves from UFRJ, Márcia Contins has worked in partnership with the PACC/CIEC School of Communication at UFRJ.

Márcia Leite has focused on the study of social movements and of violence in the city. Religion concerns her more as a resource of social 
organisation in the movements for peace and citizenship (Leite,2007, 2006b, 2005 and Birman \& Leite, 2004). Religion, as well as the Mauss' question of the gift has interested her very much (Leite, 2006a), especially in the role it can play in motivating people to move from the private sphere into the publicone. Márciahas recentlyworked in partnership with the research group co-ordinated by Luís Antônio Machado at IUPERJ.

As already mentioned, the central theme of the work by Rosane Prado (2003and 2006ae 2006b) is the environmental movement.Focusingher field research on Ilha Grande, she has also worked in collaboration with Patrícia Birman who has researchedthis island, as well (see for instance Prado, 2003).

\section{MASTER'S DISSERTATIONS AND DOCTORAL THESES}

We have already stated the large investment made by the UERJ group in the study of Pentecostalism. It is no surprise, therefore, that this features in the theses and dissertations of the students. The first dissertation of the programme as a whole, defended in August 1997, was on Pentecostalism and supervised by Patrícia Birman: The language of the funkster - innovations and conversionstrategies in neo-Pentecostal churches in Rio de Janeiroby Márcia Leitão Pinheiro, (currently professor at the North Fluminense State University, UENF). Like this one, the other three dissertations defended soon thereafter in that year and also in 1998 had Pentecostalism as their theme. They were as follows: Rites of the Kingdom of God: Pentecostals and ritualinsertion (by Patrícia Guimarãessupervised by Patrícia Birman), Religious conversion of prisoners, a study on the process of religious conversion in the prison context (by Edigar Amorim, supervised by Cecília Mariz) and in 1998, Demons of the Kingdom of God: the Universal Church of the Kingdom of God in Argentina (by Patrícia Maria Costa Moreira supervisedby Patrícia Birman). These works focused especially on the breaks and continuities between Pentecostalismand widerBrazilianculture and society. The dissertation, "Show of the Faith: Charisma and Media in the International Church of the Grace of God" by Joseane Cabral da Silva, supervised by Márcia Leite and defended in 2005, also focused on Pentecostalism. 
The study of the Pentecostals also reappears when the broader topic is the evangelical universe as was the case of two dissertations: that of Maria Goreth dos Santos (supervised by Cecília Mariz) “Women in the evangelical hierarchy:the female pastoral" defended in March 2002 and, Marcela Serrano, "Without 'forró' and without 'peixeira': The north-easterner with the Word" (Sem forró e sem peixeira: o nordestino com a 'Palavra'"), defended in December 2004, both supervised by Cecília Mariz. The latter work focused on devoteesfrom the north-east at the Assemblyof God.This Pentecostalchurch attracts the highest proportion of north-easterners in Rio das Pedras, the community researched. In turn, the dissertation by Maria Gorethalso focused greatly on Pentecostalismbecause she observed that it is more commonto find female pastors in Pentecostal churches, especially in those small churches founded by women. Like Edigar Amorim's work, these two dissertations adopted qualitative research methods, and sought to find the relationship between Pentecostalism and other non-religious questions: violence and crime (Edigar Amorim), gender (Maria Goreth dos Santos) and migration (MarcelaSerrano).

Because of her specialising in studies of the Protestantism, Clara Mafra was asked to co-supervise a master's dissertation and a doctoral thesis from other postgraduate programmes, as with Marcelo Natividade's dissertation "Homosexual Careers and Pentecostalism", where the emphasis was on the study of Pentecostals, defended in 2003 at the Institute of Social Medicine at UERJ, and the work by Mônica Rolo, " Therapeutic itineraries of mothers with congenital malformation", on the border between the anthropology of religion and medicine, defended at ENSP/Fiocruz in 2005.

Within the field of Pentecostalism, the Universal Church especially has inspired much reflection in theses and dissertations. The first doctoral thesis in religion, The Era of the IURD Cathedrals: authenticity on show, by Edlaine de FieldsGomes (supervised by MárciaContins) defendedin 2004 was about this church. Also investigating the IURD were the dissertations by Patrícia Guimarães, Patrícia Moreira already mentioned, as well as the dissertation by Cláudia Wolff Swatowiski (supervised by Clara Mafra), The Universal Church in the National Oil Capital: Considerations on the dynamics of mass communication in the service of God, defended in 2006. 
From one aspect, the Universal Church calls attention because of its relationship with the Afro-Brazilianreligions, whilst it fights with them and, at the same time, has an exchange going on with them. Is this a new type of syncretism? How does this Brazilian church go about its missionary project in other countries? These are the questions worked on by the professors and students of thisresearchgroup. But another aspectis thatthe UniversalChurch is winning space in the public sphere through the media, politics and most recently in the building of cathedrals. The strong presence of the Universal Church in the city of Rio de Janeiro, its rapid growth culminating in the election of a state senator, could explain this special interest,but the academic interest in the Universal Church goes beyond the limits of Rio de Janeiro, as seen in the research carried out by Oro, Corten and Douzon (2003).

Although the drop in numbers of those declaring themselves to be Catholic is still being seen in the 1990's, the news that will cause interest amongst those studying Catholicism in Brazil in this period of time will be the transformations in the practices and discourses of Catholics. In parallel with the intense growth of the Catholic Charismatic Renewal Movement, the church of liberation theology is reviewing its projects and looking for a dialogue with the more mystical currents. As shown by the different dissertations and theses on Catholicism defendedin this researchgroup, these changes, however, do not imply that Catholicismis leaving the public sphere.

Up until 2007 four dissertations and two doctoral theses were inspired by Catholicism. The dissertation by Sílvia Regina Alves Fernandes, "New wine in old skins?" An analysis of the religious femininelife in contemporary modernity" "Vinho Novo em Odres Velhos?" Uma análise da vida religiosa feminina na modernidade contemporânea") analyses a question, which is relatively little studied, the feminine religious life. The author compares four distinct types of religious congregation and discusses the dilemmas and the crisis of this type of vocation in contemporary society. The other three dissertations deal more directly with the changes in Catholicism described above. They are: "Community Integration Project: the crisis of a progressive Catholic group in Rio de Janeirö , by Rozicléa Nascimento defended in 2000, "Diving into God's Spirit; (im)possible dialogues between the RCC and the 
New Age in the Community of Life in the Spirit: Canção Nova (New Song)", by Eliane Martins de Oliveira, defended in 2003 and, From mysticism to utopia: an anthropological study of the Mysticism and Revolution Movement for new reflections on Youth, Religion and Politics by Paulo Cézar Batista, defended in 2005. The latter was supervised by Patrícia Birman and the three former ones were supervised by Cecília Mariz.

As we have already stated, these transformations in Catholicism also inspired two doctoral theses "Religious Experiences - A Study on Mysticism and Autonomy in the discourses and practices of Catholics of liberation and charismatic Catholics" by Andréa Damacena Martins (2004) and "Being a priest to be a saint"; "Being a nun to ser ve". The social construction of the religious vocation - a comparative analysis amongst boys and girls in Rio de Janeiro" in 2004 by Sílvia Regina Alves Fernandes (currently Rural FederalUniversity of Rio de Janeiro/UFRRJ professor), supervised by Cecília Mariz. Both UERJ doctoral candidates had had experience of research at CERIS. Therefore a kind of exchange with the NGOs has still been going on in recent times. Indeed, experience with NGOs seems to have marked the trajectory of various students. Edigar Amorim, for example, chose to work with the Pentacostalists in prison through research at ISER with Luis Eduardo Soares, also professor at PPCIS. Rozicléa Nascimento also had experience at ISER before studying for her master's degree, being supervised in the graduation monograph and Scientific Initiation at UFRJ by Regina Novaes. The exchange between NGOs and postgraduates still continues.

The choice of theme thus depends not only on the events and the characteristics of religious field, but also on the trajectories and personal experiences of the researchers. In the analysis of those master and doctoral students who researched Catholicis $m$ in their theses and dissertations we can see a prior involvement in liberation Catholicism. In their research into Catholicis m, these postgraduate students in one way or another deal with the crisis of this politicisedreligiousness and the arising of new practices, whether charismatic or otherwise.

The Afro-Brazilian religionsinspired the least amount of researchduring the period being analysed, despitetwo professors, Patrícia Birmanand Márcia

Debatesdo NER, Porto Alegre, ANo 8, N. 11, P. 21-47, JAN./Jun. 2007 
Contins, having done much research in this group in the 1980's. In PPCIS, only two dissertations on the Afro-Brazilian religions were defended, both supervised by Patrícia Birman: "It's time for you to ask": a photo-ethnography on the experience of incorporation in the Umbanda yard" (by Adriana dos Santos Fernandes) in 2001 and "Utopia hunters: constructions of identities and associations between religion and politics in Rio de Janeiro" by Luiz Fernandes de Oliveira in 2002.

Easternreligions and other practiœs connected with what has been called New Age was the theme of three master's dissertations and one doctoral thesis. Amongst the dissertations we have: Modernity and religiaus globalisation: "New Age" in Rio de Janeiro/Brazil and San Sebastián/Spain by Maria Lúcia Tauil Bernardo supervised by Cecília Mariz and defended in July 1999, "OM SAI RAM: Meetings and passings in the Brazilian religious field" by Alberto Calil Elias Junior supervised by Patrícia Birman, in 2004, and "Searching by young people: participation and belonging of messianic youth from the Johrei Center Andarai" by Maurício França Fabião in 2005, supervised by Márcia da Silva Pereira Leite. Lastly, one doctoral thesis dealt with this type of religiousness "Imagine if all this were true": the Raelian Movement in cities, nations and religions of modernity by Carly Barboza Machado (supervised by Patricia Birman) defended in October 2006. Researching a group considered to be a type of international sect, Carly Machado's thesis is interwoven with her supervisor's work about the anti-cult movement in France (Birman, 2000, 2005a).

Still on the theme of religion but not focusing on any specific religious group, we have the master's dissertation by Ana Cecília Pachaco, "Spirituality in school: affection, the word and silence. An ethnography of a 'non-conventional' study" supervised by Patrícia Birman, defended in 2002.

However, as we have said before, the professors of this research group have supervised studies are not necessarily connected to religion. Themes covered have been violence (with the thesis "Violence and social identity: a comparative study of police action in two Rio de Janeiro communities" by Jorge da Silva, supervised by Márcia Contins and defended in 2005 and the dissertation "Tragedy and Accommodation: an anthropology of the murder of 
journalist Tim Lopes"by Robson de Paula, supervised by ClaraMafra, defended in 2004), the environment (thesis "The environmentalising process and environmental etiquette of the company 'thinkinggreen': the case of the National Steelworks Company" by Silvia Borges Corrêa, defended in 2006, and the dissertations "Socio-political participation in the environmental management of the Navy reserve at Arraial do Cabo'by Marcus Machado Gomes in 2005 and "Is there environment in the slums? Environmentalism in Serra da Misericórdia" by Eduardo Simas in 2007, all supervised by Rosane Prado). Then there is the work on other social movements, such as the Landless Workers Movement,MST (the dissertation "Cultivatingidentities: the native seed and the peasant invention in the MST 'Seeds Campaign"' by Cecilia Moreyra de Figueiredo defended in 2006 and supervised by Márcia Leite), and the negro movement (the thesis "Beyond racism and anti-racism: the production of a Culture of Black Consciousness in Brazilian society" by Amauri Mendes Pereira, supervised by Márcia Contins in 2006), and other social movements (the dissertation "Voluntary Work: considerations on giving and recei ving" by Andréa Freitasda Silva, supervised by Márcia Contins defended in 2006). Another theme observed has been popular culture (the thesis "A Way of Life: the organisation of the world of rodeos in Brazil" by Simone Pereira da Costa in 2003, and the dissertation "The market and the shopping centre in popular culture" by Ruth Helena de Souza Britto of 2002, both supervised by Patrícia Birman).

\section{FINAL CONSIDERATIONS}

To round up, we would like to point out that this research group has tried to understand religion in a globalised world and has encouraged international research and comparisons. Before going to UERJ, Márcia Contins, in her doctoral thesis, compared the Black Pentecostals in the US with Brazilian Black Pentecostals. Also in her doctoral thesis, Clara Mafra made the international comparison of the Universal Church in Brazil with that of Portugal. In her turn, Patrícia Birman, defended in 2000 her thesis for full Professorship based on research in Franceon the anti-sect movement, focusingon the differences in attitudesbetween the Frenchand the Brazilians in relation to religion and the laity.

Debatesdo NER, Porto Alegre, ANO 8, N. 11, P. 21-47, JAN./JUn. 2007 
Students have also been motivated to do research in other countries on projects that until very recently would have been considered inappropriate or unviable in Brazil. In order to study the international Raelian network, Carly Machado did her doctoral thesis field work in Europe and Brazil. Two master's dissertations have dealt with international comparisons: Maria Lúcia Bernardo comparing Rio de Janeiro and San Sebatian (Spain), and Patrícia Moreira comparing the Universal Church in Rio de Janeiro with that in Buenos Aires. Although the decision to make this kind of comparison can be explained by the personal journeys of the authors, the mobility to be able to carry them out as well as the international personal biography themselves show how globalisation has broadened our everyday lives. Supervision can be done via e-mail, air tickets have become cheaper, and so without the support for international research in the master's degree, these have occurred through the globalisation of our everyday lives and personal relationships. Wealso highlight the exchange experiences among doctoral students.

Whilst two UERJ doctoral students went to study at Amsterdam Vrije Universiteit, VUA (Andréa Damacena Martins in 2001 and Carly Barbosa in 2005), a studentfrom École des Hautes Études SciencesSociales (EHESS), France,AmandaDias, whosethesisis co-supervised by PatríciaBirman,came to UERJin order tocompleteher workdiscussingreligion andviolenc, comparing a Palestinian Muslim refugees camp with the Acari "favela" in Rio de Janeiro.

It is importantto rememberthat variousresearchersin thegroup integrated their work into the project "Religious Movements in the Contemporary World" under the Centres of Excellence Support Programme (PRONEX), 1998 publication, which brings together researchers from UFRGS, UnB, USP and UFRJ (IFCS and National Museum) under the general coordination of Professor Dr. JoséJorge de Carvalho(UnB). This line of research has an interface with the Anthropology and Images Nucleus at UERJ, which affords the development of an anthropology and sociology of the image, the media and cinema, associated to the field of religion and social movements. In this scope, extension programmes have been set up relating to the slum resident's and ecology movements, as well as to the production of instruments of visual language. 


\section{REFERENCES}

BIRMAN, Patrícia. Cultos afro-brasileiros ou como falar de nação, gênero e etnicidade falando de religião? Não-publicado, 2007.

OEspírito Santo,a mídia e o território dos crentes.Ciencias sociales y religión/Ciências sociais e religião,v. 8, p. 41-62, 2006.

. Fronteiras espirituais e fronteiras nacionais: o combate às seitas na França. Mana, Rio de Janeiro, v. 11, p. 7-39, 2005a.

.Transase transes: sexoe gêneronos cultosafro-brasileiros, um sobrevôo. Estudos Feministas, Florianópolis, v. 13, n. 1, 2005b. . (Ed.). Religião e Espaço Público. Rio: Attar, 2003.

Religiosidade, pluralismo e nação: as seitas na Françahoje. Thesis (Oficial examination - Professor in Anthropology) - UERJ, 2000.

BIRMAN, P.; LEITE, M. P. (Ed.). Um Mural para a Dor. cívico-religiosos por justiça e paz. Porto Alegre: UFRGS/Pronex, 2004.

BIRMAN, P.; LEITE, M.; CARNEIRO, S. Entre a política e a religião: experiências e trajetórias de cientistas sociais da geração 68/70. Numen, Juiz de Fora-MG, v.7, n.1, p. 81-104, 2004.

CARNEIRO,Sandra de Sá. Religião nas escolas públicas: questões nacionais e a situação no Rio de Janeiro. Revista Contemporânea de Educação, Rio de Janeiro, n. 02, p. 01-03, 2006.

Novas peregrinações brasileiras e suas interfaces com o turismo. Cienciassociales y religión/Ciênciassociais e religião, PortoAlegre, n. 6 , p. 71-100, 2004a.

Pesquisa via Internet:desafios e perspectivas do trabalho antropológico. Cadernos de Antropologia e Imagem, v. 18, n. 1, p. 189-210, 2004b. 
Rumo a Santiago de Compostela: os sentidos da peregrinação moderna, Thesis de Doutoramento em Antropologia, IFCS/ UFRJ, 2003a.

Caminhos de Santiago de Compostela: percurso, identidade e passagens. In:BIRMAN,Patrícia. (Ed.).Religião e EspaçoPúblico. São Paulo: Attar, 2003b, p. 259-281.

CARNEIRO, S.; FREIRE-MEDEIROS, B. Antropologia,religião e turismo: múltiplas interfaces. Religião \& Sociedade, v. 24, p. 100-125, 2005.

CAMURÇA, Marcelo A. Da "boa” e da "má" vontade para com a religião nos cientistas sociais da religião brasileiros. Religião \& Sociedade, Rio de Janeiro, v. 21, n.1, p. 67-86, 2001.

CONTINS, Márcia; GOMES, Edlaine de Campos. Os Percursos da Fé: uma análise comparativa sobre as apropriações religiosas do espaço urbano entre pentecostais e carismáticos. Revista do Núcleo de Antropologia Urbana da USP/Ponto Urbe, São Paulo, v. 1, 2007.

CONTINS, Márcia. Os Pentecostais e as Religiões Afro-Brasileiras. Textos escolhidos de cultura e arte populares, Rio de Janeiro, v. 2, p. 37-50, 2005a.

Lideranças Negras Rio de Janeiro: FAPERJ/Aeroplano,

2005b.

Objetivos e Estratégias da Ação Afirmativa: uma

bibliografia. BIB. Revista Brasileira de Informação Bibliográfica em Ciências Sociais, São Paulo, n. 57, p. 91-102, 2004a.

Subjetividade e Alteridade:os pentecostaisnegros no Brasil

e nos Estados Unidos. Logos, Rio de Janeiro, v.11, n. 21, p. 150-174, 2004b.

FERNANDES, Rubem César; VELHO, Otávio; SANCHIS, Pierre;

CARNEIRO, Leandro P;; MARIZ, Cecília;MAFRA, Clara Novo Nascimento - os evangélicos em casa, na igreja e na política. Rio de Janeiro: Ed. Mauad, 1998.

Censo Institucional Evangélico CIN 1992 - Primeiros

Comentários. Textos de Pesquisa. Rio: ISER, s/d. 
LANDIM, Leilah. "Experiência militante": histórias das assim chamadas ONGs. In: Ações em sociedade - militância, caridade, assistência, etc. Rio de Janeiro. ISER/NAU, 1998, p. 23-89.

LEITE, Márcia Pereira. Religião e política no espaço público: movimentos de moradores de favelas contra a violência e por justiça. In: ALMEIDA, Ronaldo de; MAFRA, Clara. (Ed.). Religiões e Cidades: Rio de Janeiro e São Paulo. São Paulo: CEM/CEBRAP e Pronex/CNPq, 2007 (no prelo).

.Dádiva e missãoentre familiares de vítimas de violência.

In: MARTINS, Paulo Henrique; CAMPOS, Roberta Bivar (Ed.). Polifonia do Dom. Recife: Editora Universitária UFPE, p. 165-208, 2006a.

. Na tela o povo e a nação: classes populares e periferias em imagens. In: FREIRE-MEDEIROS, Bianca; COSTA, Maria Helena (Ed.). Imagens Marginais. Natal: Editora da UFRN, 2006b, p. 39-56.

The favelasof Rio de Janeiro in Brazilian cinema (1950 to 2000). In: VIEIRA, Else R. P. (Ed.). City of God in Several Voices: Brazilian Social Cinema as Action. CCCP: Critical, Cultural and Communications Press, 2005, p. 149-165.

MACHADO, Mariadas DoresCampos; MARIZ,Cecília.Religião, mulheres e política institucional: evangélicas e católicas. In: SOUZA, Sandra Duarte de (Ed.). Gênero e religião no Brasil: feministas. São Bernardo do Campo, SP: Universidade Metodista de São Paulo, 2006, p. 45-68.

MAFRA, Clara C. J. Os Evangélicos. Rio de Janeiro: Jorge Zahar, 2001. Na Posse da Palavra. Lisboa: Imprensa de Ciências Sociais - Universidade de Lisboa, 2002. Jesus Cristo Senhor e Salvador da Cidade - Imaginário Crente e Utopia Política. Dados, Rio de Janeiro, v. 49, p. 583-614, 2006. Casa de Deus, Casa dos Homens. Análise Social, Lisboa, v. 182, p. 145-161, 2007. 
MAFRA, Clara; SWATOWISKI, Cláudia. O balão e a catedral - trabalho, lazer e religião na paisagem carioca. Anthropológicas, Recife, 2007 (no prelo).

MARIZ, Cecília Loreto. La enseñansa y la investigaciónen la sociología de la religión en Brasil. In: FRIGERIO, Alejandro (Ed). Ciencias sociales y religión en el Cono Sur. Aires: Centro Editor de America Latina, 1993, p. 72-85.

Comunidades de vida no Espírito Santo: juventude e religião. Tempo Social, São Paulo, v. 17, n. 2, p. 253-274, 2005.

.Catolicismo no Brasil Contemporâneo: Reavivamento e Diversidade.In: TEXEIRA, Faustino;MENEZES, Renata(Ed.). As Religiões no Brasil: Continuidades e Rupturas. Petrópolis: Vozes, 2006, p. 53-68.

MARIZ, Cecília; MACHADO, Maria das Dores; DROGUS, Carol Ann; STEWART-GAMBINO, Hannah. Catholics and Pentecostals: Possibilities for Alliance. In: DROGUS, Carol Ann; STEWART-GAMBINO, Hannah (Ed.). Activist Faith: Grassroots Women in Democratic Brazil and Chile. University Park:The Pennsylvania State University Press, 2005, p.129-153.

MARIZ, Cecília; PERES, Vitória. Conversion to Islam in Contemporary Brazil. Exchange, The Netherlands, v. 35, n. 1, p. 102-115, 2006.

NOVAES, Regina. Religião e Sociedade, vinte anos: entrevista com Rubem César Fernandes. Religião \& Sociedade, Rio de Janeiro, v. 18, n. 2, p. 7-28, 1997.

ORO, Ari Pedro. El estudio de la religión desde las ciencias sociales en el Brasil. In: FRIGERIO, Alejandro (Ed.). Ciencias Sociales y religión en el Cono Sur. Buenos Aires: Centro Editor de America Latina, 1993, p. 86-92.

ORO, Ari Pedro; CORTEN, André; DOZON, Jean-Pierre (Eds). Anexo: Teses e dissertações sobre Igreja Universal do Reino de Deus defendidas no Brasil e no exterior. In: Igreja Universal do Reino de Deus - os novos conquistadores da fé.São Paulo: Paulinas, 2003, p. 365-379.

PRADO, Rosane. (2003) Crentes na Ilha Grande: uma forma de ser nativo. In: BIRMAN, Patrícia (Ed.). Religião e Espaço Público. São Paulo: Attar Editorial/CNPq/Pronex, 2003, p. 123-146. 
Janeiro: EdUERJ, 2006a.

(Ed.). Ilha Grande: do sambaqui ao turismo. Rio de Depois que entrou o IBAMA: percepção de questões ambientais na Ilha Grande.In: PRADO,Rosane Manhães(Ed.). Ilha Grande: do sambaqui ao turismo. Rio de Janeiro: EdUERJ, 2006b.

PRADO, Rosane Manhães; SANTOS, MyrianSepúlveda dos (Ed.). Coleção Ilha Grande. Rio de Janeiro: EdUERJ, 2003.

REYES HERRERA, Sonia E. Reconstrução do Processo de Formação e Desenvolvimento da Área de Estudos da Religião nas Ciências Sociais.Thesis (PhD - Sociology)-PPGS/UFRGS, Porto Alegre, 2004.

SANCHIS, Pierre (Ed.). Catolicismo: modernidade e tradição. São Paulo: Loyola, 1992a.

SANCHIS, Pierre (Ed.). Catolicismo: cotidiano e movimentos. São Paulo: Loyola, 1992b.

SANCHIS, Pierre (Ed.). Catolicismo: religiosa e pluralismo cultural. São Paulo: Editora Loyola, 1992c.

THEIJE,M.; MARIZ,C. L. Localizing and GlobalizingProcesses in Brazilian Catholicism: Comparing Inculturation in Liberationist and Charismatic Catholic Cultures. Latin American Research Review (LARR), Austin, v. 43, n. 1, 2008 (no prelo).

VELHO, Otávio. "Trabalhos de campo, antinomias e estradas de ferro". Interseçôes, Rio de Janeiro, ano 8, n. 1, p. 9-27, 2006.

O cativeiro da Besta Fera. In: Besta-Fera - recriação do Mundo.

Rio de Janeiro: Relume-Dumará, [1987]1995, p. 13-44.

(Translated by Colin Mansell) 
ANNEXE: Themes of the theses and dissertations on religion supervised by UERJ Religion and Social Movements Research Group - 1997-2007.

\begin{tabular}{lc}
\hline \hline & Defesis \\
\cline { 2 - 2 } Subject miatter & Number \\
\hline Pentrecostalism & 8 \\
Catbolicism & 6 \\
New Religious and New Age & 4 \\
Moremeats & \\
Afro Religions & 2 \\
Religion in the school & 1 \\
Taral & 21 \\
\hline \hline
\end{tabular}

Debates do NER, Porto Alegre, ano 8, N. 11, P. 21-47, JAN./Jun. 2007 
